\title{
SINTESIS MEMBRAN KOMPOSIT BERBAHAN DASAR KITOSAN DENGAN METODA SOL-GEL SEBAGAI MEMBRAN FUEL CELL PADA SUHU TINGGI
}

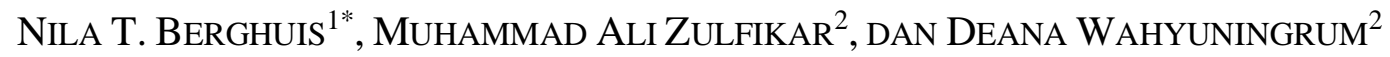 \\ ${ }^{1}$ Program Studi Kimia, Fakultas Sains dan Komputer, Universitas Pertamina, \\ Jalan Teuku Nyak Arief, Simprug Jakarta Selatan 12220 \\ ${ }^{2,3}$ Departemen Kimia, Fakultas Matematika dan Ilmu Pengetahuan Alam, Institut Teknologi Bandung, \\ Jalan Taman Sari No.10 Bandung
}

*alamat email korespondensi: nila.tanyela@universitaspertamina.ac.id

\begin{tabular}{l} 
Informasi Artikel \\
\hline Riwayat Naskah : \\
Diterima pada 4 \\
Desember 2019 \\
Diterima setelah \\
direvisi pada 26 Juni \\
2020 \\
Diterbitkan pada 30 \\
Juni 2020
\end{tabular}

Kata Kunci: Kitin; kitosan; membran kitosan-TEOS; solgel; fuel cell.

Keywords: chitin; chitosan; chitosanTEOS membrane; sol-gel; fuel cell.

\section{Abstrak/Abstract}

Kitosan adalah polisakarida kationik yang terdiri dari residu glukosamin dan $\mathrm{N}$-asetil glukosamin yang terikat oleh ikatan $\beta-1,4$ glikosidik. Keberadaan gugus alkohol bebas pada kerangka kitosan dapat dimanfaatkan sebagai gugus pembentuk matrik dengan atom lainnya, dalam penelitian ini adalah silika (Si). Kondisi ini dapat dimanfaatkan sebagai bahan dasar sintesis membran sel bahan bakar (Fuel Cell). Sintesis kitosan dilakukan dengan mendeasetilasi kitin yang bersumber dari limbah kulit udang. Membran komposit kitosanTEOS (Tetraetilortosilikat) telah berhasil disintesis dengan menggunakan variasi nilai konsentrasi kitosan terhadap jumlah TEOS. Membran komposit kitosan-TEOS disintesis dengan menggunakan metoda sol-gel dan pembalikan fasa. Kitosan dan membran komposit yang dihasilkan kemudian dikarakterisasi sifat kimia dan fisika nya yaitu penentuan derajat deasetilasi, penentuan berat molekul rata-rata (Mv), persen kelarutan, analisis struktur dengan menggunakan FTIR, uji ketahanan suhu, analisis morfologi dengan menggunakan SEM, dan kapasitas pertukaran ion (KPI). Hasil karakterisasi menunjukkan derajat deasetilasi kitosan sebesar 79,31\% dengan nilai berat molekul rata-rata $(\mathrm{Mv}) 1,16 \times 10^{7} \mathrm{~g} / \mathrm{mol}$ dan persen kelarutan $1 \%(\mathrm{v} / \mathrm{v})$ asam asetat. Hasil pengukuran FTIR membran menunjukkan terdapat puncak $1377 \mathrm{~cm}^{-1}$ yang merupakan puncak dari eter siklik, puncak $3454 \mathrm{~cm}^{-1}$ yang merupakan puncak dari O-H, puncak pada $1662-1666 \mathrm{~cm}^{-1}$ yang merupakan puncak dari $\mathrm{C}=\mathrm{O}$ asetamida, dan 3454-3500 $\mathrm{cm}^{-1}$ yang merupakan puncak N-H, sedangkan puncak $904 \mathrm{~cm}^{-1}$ dan $1091,7 \mathrm{~cm}^{-1}$ menunjukkan adanya ikatan silang antara Si-OH dan Si-O-C (alifatik). Uji ketahanan membran terhadap suhu sebesar $120^{\circ} \mathrm{C}$ sedangkan nilai konduktivitas ionik terbesar dimiliki oleh tipe membran CTSN-1,5 dengan nilai 0,114 meq/g. Hasil analisis SEM menunjukkan bahwa membran mempunyai struktur yang rapat.

Chitosan is a cationic polysaccharide consisting of glucosamine and $\mathrm{N}$-acetyl glucosamine residues which are bound by glycosidic $\beta-1,4$ bonds. The existence of free alcohol groups in the chitosan framework can be used as a matrix-forming group with other atoms, in this study is silica ( $\mathrm{Si}$ ). This condition can be utilized as a basic ingredient in the synthesis of fuel cell membranes. Chitosan synthesis by deacetylation of chitin which is sourced from shrimp shell waste. Chitosan-TEOS (Tetraethylortosilicate) composite membrane has been successfully synthesized by using variations in the value of chitosan concentration to the amount of TEOS. Chitosan-TEOS composite membrane was synthesized using the sol-gel method and phase reversal. Characterization of Chitosan and composite membranes include chemical and physical properties, which is a determination of the degree of deacetylation, determination of average molecular weight $(\mathrm{Mv})$, percent solubility, structural analysis using FTIR, temperature resistance test, morphological analysis using SEM, and exchange capacity ion (KPI). The characterization results showed that the degree of deacetylation of chitosan was $79.31 \%$ with an average molecular weight $(\mathrm{Mv})$ value of $1.16 \times 107 \mathrm{~g} / \mathrm{mol}$ and a percent solubility of $1 \%(\mathrm{v} / \mathrm{v})$ of acetic acid. The results of FTIR membrane measurements show that there is a peak of $1377 \mathrm{~cm}^{-1}$ which is the peak of the cyclic ether, peak of $3454 \mathrm{~cm}^{-1}$ which is the peak of $\mathrm{OH}$, the peak at $1662-1666 \mathrm{~cm}^{-1}$ which is the peak of $\mathrm{C}=\mathrm{O}$ acetamide, and 3454$3500 \mathrm{~cm}^{-1}$ which is the peak of $\mathrm{NH}$, while peaks of $904 \mathrm{~cm}^{-1}$ and $1091.7 \mathrm{~cm}^{-1}$ indicate the presence of cross bonds between $\mathrm{Si}-\mathrm{OH}$ and $\mathrm{Si}-\mathrm{O}-\mathrm{C}$ (aliphatic). The temperature resistance test of the membrane at $120^{\circ} \mathrm{C}$ while the greatest ionic conductivity value is owned by the membrane type CTSN-1.5 with a value of $0.114 \mathrm{meq} / \mathrm{g}$. SEM analysis results show that the membrane has a tight structure. 


\section{PENDAHULUAN}

Permasalahan yang tengah dihadapi dunia saat ini adalah masalah global warming yang dipicu karena penggunaan bahan bakar serta krisis bahan bakar mineral (minyak bumi). Kemampuan negaranegara di dunia untuk menyediakan bahan bakar semakin lama semakin berkurang hingga suatu saat akan mencapai puncaknya, karena hampir semua daerah yang mengandung minyak telah ditemukan dan dieksplorasi. Sedangkan permintaan akan bahan bakar terus meningkat dengan tajam, sehingga cadangan minyak dunia semakin menipis [1]. Untuk mengatasi permasalahan di atas, sekiranya kita perlu untuk mencari alternatif energi pengganti yang terbaharukan (renewable energy) dan berkelanjutan serta ramah lingkungan seperti :biofuel, geothermal, sel bahan bakar (fuel cell), dan lain-lain.

Diantara energi alternatif tersebut, yang menjanjikan adalah fuel cell [2]. Fuel cell merupakan sebuah alat elektrokimia yang mirip dengan baterai. Bedanya, fuel cell dirancang untuk terus memiliki energi. Satu sel individu dari fuel cell terdiri dari anoda, katoda serta elektrolit. Teknologi fuel cell terbagai ke dalam beberapa tipe diantaranya PEMFC (Proton Exchange Membrane Fuel Cell) dan DMFC (Direct Methanol Fuel Cell). Pada sistem fuel cell ini elektrolit yang digunakan adalah membran [3]. Beberapa membran yang telah dikembangkan untuk aplikasi ini diantaranya berbahan dasar karet silikon termodifikasi, metakrilat, kopolimer poliester, poliakrilonitril, polimer ikatan silang, polimer blok atau cangkok, dan lain sebagainya. [4]. Membran yang saat ini paling banyak digunakan sebagai elektrolit dalam Direct Methanol Fuel Cell (DMFC) adalah Nafion yang diproduksi oleh Du Pont. Nafion ${ }^{\circledR}$ merupakan polimer dengan rantai utama mirip Teflon ${ }^{\circledR}$ dengan gugus sulfonat sebagai gugus sampingnya. Dalam keadaan terhidrasi penuh Nafion ${ }^{\circledR}$ mempunyai nilai konduktivitas $10^{-2}-10^{-1} \mathrm{~S} \mathrm{~cm}^{-1}$, namun nafion ini tidak ramah lingkungan karena kandungan unsur flour, memiliki crossover metanol yang tinggi yang akan menurunkan efisiensi fuel cell serta konduktivitas Nafion ${ }^{\circledR}$ menurun secara drastis pada suhu di atas $90^{\circ} \mathrm{C}$ karena adanya penurunan kadar air dalam membran [5].

Untuk mengatasi kelemahan-kelemahan ini maka diperlukan suatu polimer lain yang dapat menggantikan peran Nafion. Salah satu polimer yang berpotensi sebagai pengganti Nafion ${ }^{\circledast}$ adalah kitosan. Kitosan merupakan produk deasetilasi kitin yang banyak terdapat pada kulit hewan crustaceae seperti udang, lobster dan kepiting. Kitosan mempunyai gugus amina bebas yang dapat terprotonasi, sehingga dapat dikategorikan sebagai polikation alami. Selain gugus amina bebas, kitosan juga memiliki gugus hidroksi. Kedua gugus ini memungkinkan dilakukannya modifikasi pada kitosan untuk menghasilkan sifat fisik dan kimia yang diinginkan. Menurut Smitha dkk. [6] diketahui juga bahwa crossover metanol pada kitosan lebih rendah daripada Nafion ${ }^{\circledR}$.

Pengikatsilangan kitosan adalah solusi yang ditawarkan untuk mengatasi permasalahan sifat mekanik dari kitosan. Penelitian yang sudah dilakukan diantaranya dengan glutaraldehid asam sulfat dan senyawa epoksi [7]. Penelitian lainnya, pembentukan organik-anorganik material memberikan pendekatan lain untuk membuktikan karakteristik fisik dan kimia dari kitosan dan biomaterial lainnya. Memperkenalkan silika ke dalam biomaterial dapat meningkatkan permeabilitas terhadap oksigen, biokompatibiliti dan biodegradabiliti. Serta ketahanan fisik terhadap suhu tinggi. Penelitian ini bertujuan untuk mensintesis kitosan sebagai bahan dasar dalam sintesis membran kitosan-TEOS yang dapat diaplikasikan sebagai membran elektrolit dalam Direct Methanol fuel cell (DMFC). Membran kitosan-TEOS disintesis dengan proses sol-gel melalui metode inversi fasa yang kemudian diuji ketahanan suhu, difusi metanol, serta nilai konduktivitas proton yang menjadi parameter dalam perkembangan Direct Methanol Fuel Cell dalam bidang energi. Dalam jangka panjang diharapkan penelitian ini dapat memacu pengembangan bahan alam lain sebagai pengganti Nafion ${ }^{\circledR}$ dan pengembangan fuel cell di Indonesia.

\section{EKSPERIMEN}

Prosedur penelitian ini terdiri dari beberapa tahap, tahap pertama sintesis kitosan yang terdiri dari isolasi kitin dari kulit udang, konversi kitin menjadi kitosan. Tahap ke dua adalah sintesis membran kitosan-TEOS melalui proses sol-gel serta karakterisasi meliputi karakterisasi kitosan, diantaranya karakterisasi FTIR, penentuan berat molekul rata-rata $(\mathrm{Mv})$, persen kelarutan didalam larutan asam asetat, dan derajat deasetilasi sedangkan karakterisasi membran kitosan-TEOS diantaranya analisis spektrofotometri FTIR, derajat penyerapan air, uji ketahanan suhu, kapasitas penukar ion, permeabilitas metanol, konduktivitas proton, dan SEM.

\section{Material}

Limbah udang (lokal), $\mathrm{NaOH}_{(\mathrm{aq})} 3,5 \% \mathrm{~b} / \mathrm{v}$, $50 \% \mathrm{~b} / \mathrm{v}, \mathrm{NaOH}_{(\mathrm{aq})} 0,1 \mathrm{M}, \mathrm{NaOH}_{\text {(aq) }} 1 \mathrm{M}$, larutan $\mathrm{HCl}$ $1 \mathrm{M}, 0,1 \mathrm{M}$, Larutan asam asetat $3 \%$, TEOS (tetraethylorthosilicate) $99,8 \% \quad$ (p.a) Sigma Aldrich), Aseton teknis (lokal), Aqua dm (lokal). 


\section{Instrumentasi}

FTIR One Perkin Elmer, Viskometer Ostwald Autograph Shimadzu, Gas Chromatography Merck, A Hewlett-Packard Impedance/Gain-phase Analyzer (model 4194A) Hot Plate Stirrer, Oven, Neraca digital, Alat-alat gelas, Mortar dan alu, Seperangkat alat Soxhlet.

\section{Prosedur}

Prosedur Sintesis kitosan diadopsi dari penelitian yang dilakukan oleh Hong. K, dkk. [8]. Untuk memperoleh kitosan, dapat dilakukan melalui tahapan isolasi kitin serta konversi kitin menjadi kitosan seperti terlihat pada Gambar 1 dibawah ini.

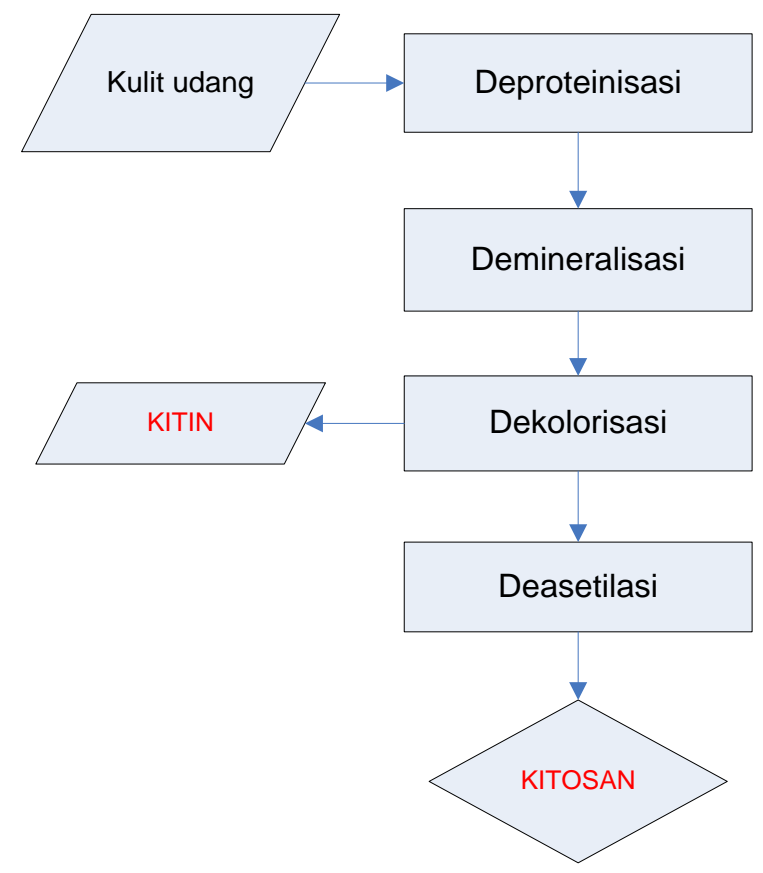

Gambar 1. Tahapan sintesis kitosan dari kulit udang.

\section{Sintesis Membran Kitosan}

Kitosan sebanyak $1 \mathrm{~g}$ dilarutkan dalam 100 $\mathrm{mL}$ larutan asam asetat 3\%. Larutan kemudian disaring dan dituangkan ke dalam cawan Petri masing-masing $20 \mathrm{~mL}$. Larutan dibiarkan menguap selama 2 hari pada suhu ruang atau dapat juga di oven $50^{\circ} \mathrm{C}$ selama 12 jam hingga didapatkan padatan membran. Kemudian membran direndam di dalam larutan $\mathrm{NaOH} 2 \mathrm{M}$ selama 15 menit kemudian dicuci dengan aqua dm hingga larutan $\mathrm{NaOH}$ hilang.

\section{Sintesis Membran Kitosan-TEOS}

Larutan kitosan $1 \%$ dituangkan sebanyak 20 $\mathrm{mL}$ ke dalam cawan petri, kemudian ditambahkan
TEOS dengan komposisi $0,5 \mathrm{~mL} ; 1 \mathrm{~mL} ; 1,5 \mathrm{~mL}$; dan $2 \mathrm{~mL}$. Larutan membran kemudian di biarkan di dalam oven bersuhu $50^{\circ} \mathrm{C}$, selama 12 jam. Untuk pelepasan membran dari cawan Petri dapat digunakan larutan $\mathrm{NaOH} 2 \mathrm{M}$, dengan cara direndam kemudian dicuci dengan aqua $\mathrm{dm}$ dan dikeringkan pada suhu ruang.

\section{Karakterisasi Kitosan}

Karakterisasi yang dilakukan antara lain penentuan gugus fungsi dengan analisa spektrofotometri FTIR, penentuan derajat deasetilasi, penentuan massa molekul rata-rata kitosan (Mv), dan persen kelarutan kitosan didalam larutan asam asetat $1 \%$, dan $3 \%$.

\section{Karakterisasi Membran Kitosan-TEOS}

\section{Analisis spektrofotometri FTIR}

Membran yang akan dianalisa dikeringkan kemudian dimasukan ke tempat cuplikan dan direkam spektra infra merahnya pada bilangan gelombang $4000-650 \mathrm{~cm}^{-1}$.

\section{Derajat penyerapan air}

Sampel membran yang telah diketahui massanya direndam selama 48 jam dalam air, kemudian permukaan membran dikeringkan dengan tisu dan ditimbang. Derajat penyerapan air dihitungkan menggunakan persamaan yang dilakukan oleh Campo, dkk. [9].

\section{Kapasitas penukar ion $\left(\right.$ Ion $\left.\mathrm{H}^{+}\right)$}

Membran yang sudah ditimbang, kemudian direndam didalam larutan $\mathrm{HCl} 1 \mathrm{M}$ sebanyak 30 $\mathrm{mL}$ selama satu jam. Membran di tiriskan kemudian di bilas dengan hati-hati oleh aqua $\mathrm{dm}$ hingga $\mathrm{pH}$ netral (5-6). Setelah itu direndam kembali dengan $\mathrm{NaOH} 0,1 \mathrm{~N}$ selama 30 menit. Kemudian dititrasi dengan $\mathrm{HCl}$ 0,1 N. Banyaknya ion $\mathrm{H}^{+}$yang terserap oleh membran dihitung.

\section{Parameter suhu terhadap membran}

Sampel membran semua tipe (CTSN; CTSN -0,5; CTSN-1; CTSN-1,5; CTSN-2) yang sudah diketahui beratnya di oven pada variasi temperature $60^{\circ} \mathrm{C} ; 80^{\circ} \mathrm{C} ; 100^{\circ} \mathrm{C} ; 120^{\circ} \mathrm{C}$; dan $150^{\circ} \mathrm{C}$. Dengan variasi waktu pemanasan di dalam oven : 2 jam; 5 jam; 10 jam; 15 jam; dan 24 jam.

\section{Penentuan permeabilitas metanol}

Membran dengan diameter 2,75 cm berbentuk lingkaran ditempatkan pada alat difusi 
yang dirancang mandiri. Pada kompartemen A berisi metanol pa, sedangkan pada kompartemen $\mathrm{B}$ berisi aqua $\mathrm{dm}$, dilakukan pengocokan dengan kecepatan konstan, kemudian setiap 7 menit, pada sisi tabung/sel yang berisi aqua $\mathrm{dm}$, diambil sampling untuk dilakukan pengujian dengan GC (kromatografi gas). Besarnya konsentrasi yang melewati membran dihitung dengan membandingkan besarnya luas area untuk setiap pengadukan, dengan sebelumnya dilakukan GC terhadap metanol p.a.sebagai standar.

\section{Konduktivitas proton}

Perhitungan konduktivitas ion berdasarkan metode yang dikemukakan oleh mokrini dkk. [10]. Membran basah dijepit diantara dua elektroda di dalam sel yang di desain sendiri. Untuk analisis hantaran sebelumnya membran direndam di dalam larutan $\mathrm{H}_{2} \mathrm{SO}_{4} 1 \mathrm{M}$ selama 24 jam pada suhu ruang .Sebelum pengukuran, permukaan air dipindahkan lalu membran yang telah di rendam (swollen membrane), cepat-cepat di tempatkan di antara elektroda di dalam sel uji. Air yang diserap oleh membran dianggap konstan selama jangka waktu yang relatif pendek.

\section{Analisis SEM}

Sampel membran yang memiliki nilai difusi yang baik, dilakukan SEM, untuk melihat besarnya pori-pori membran. Pengukuran SEM dilakukan di PPGL.

\section{HASIL DAN PEMBAHASAN}

Tahapan pertama dalam sintesis membran komposit kitosan-TEOS adalah sintesis kitosan dari kitin melalui reaksi deasetilasi. Kitin sebanyak 19,2602 g yang telah diperoleh direaksikan dengan larutan $\mathrm{NaOH} 50 \%$, reaksi dilakukan pada temperatur $105^{\circ} \mathrm{C}$. Suhu harus dijaga konstan berkisar $100^{\circ} \mathrm{C}-105^{\circ} \mathrm{C}$. Deasetilasi merupakan penghilangan gugus $\mathrm{N}$-asetil asetamida pada kitin menjadi gugus amina yang kita kenal dengan kitosan. Gambaran mekanisme reaksi deasetilasi kitin dapat ditunjukkan pada Gambar 2 di bawah ini.
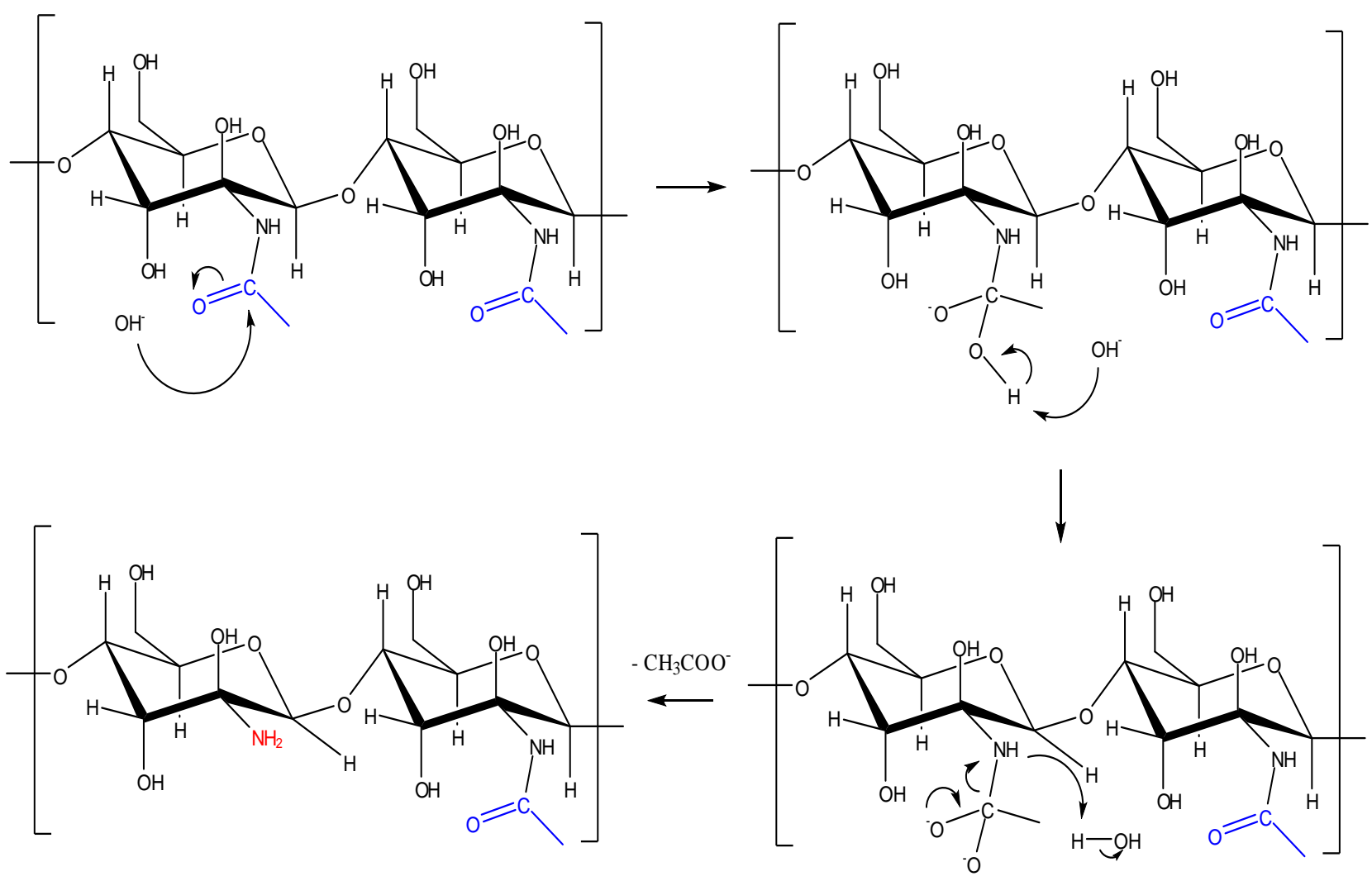

Gambar 2. Usulan Mekanisme Deasetilasi Kitin menjadi Kitosan

Banyaknya gugus asetil yang terlepas dinyatakan dengan derajat deasetilasi. Terlihat pada Gambar 2 bahwa perbedaan antara kitin dengan kitosan, terletak pada atom $\mathrm{C}$ nomor 2 . Pada kitin, semua unti monosakaridanya memiliki gugus asetamida sedangkan pada kitosan sebagian unit monosakaridanya memiliki gugus amina. Untuk memastikan telah terbentuk kitosan maka tes awal yang dapat dilakukan adalah dengan melarutkan kitosan di dalam larutan asam asetat. 
Pada penelitian ini, dilakukan pengujian kelarutan kitosan terhadap larutan asam asetat, dengan mengunakan perbandingan jumlah kitosan yang digunakan, seperti terlihat pada Tabel 1, menunjukkan bahwa pada komposisi $1 \%$ (v/v) larutan kitosan, persen kelarutannya sangat besar. Sehingga pada penelitian ini, digunakan larutan kitosan sebanyak $1 \%(\mathrm{v} / \mathrm{v})$ yaitu untuk setiap $1 \mathrm{~g}$ kitosan, ditambahkan larutan asam asetat 3\% sebanyak $100 \mathrm{~mL}$.
Tabel 1. Uji Kelarutan Kitosan.

\begin{tabular}{cccc}
\hline Kitosan & $\begin{array}{c}\text { Gram Kitosan } \\
\text { awal }(\mathbf{g})\end{array}$ & Residu $(\mathbf{g})$ & \% kelarutan \\
\hline $1 \%$ larutan & $\begin{array}{c}1,5008(150 \mathrm{~mL} \\
\text { pelarut })\end{array}$ & $0,2260 \mathrm{~g}$ & $82,27 \%$ \\
kitosan & $\begin{array}{l}\text { 2,0076 (100 } \\
\text { \% larutan }\end{array}$ & $1,3218 \mathrm{~g}$ & $34,16 \%$ \\
kitosan & mL pelarut) & & \\
\hline
\end{tabular}

Selain uji kelarutan, dapat juga dilakukan dengan pengukuran spektrum Inframerah dengan menggunakan pelet $\mathrm{KBr}$ untuk melihat gugusgugus fungsi yang terikat seperti Gambar 3 di bawah ini.

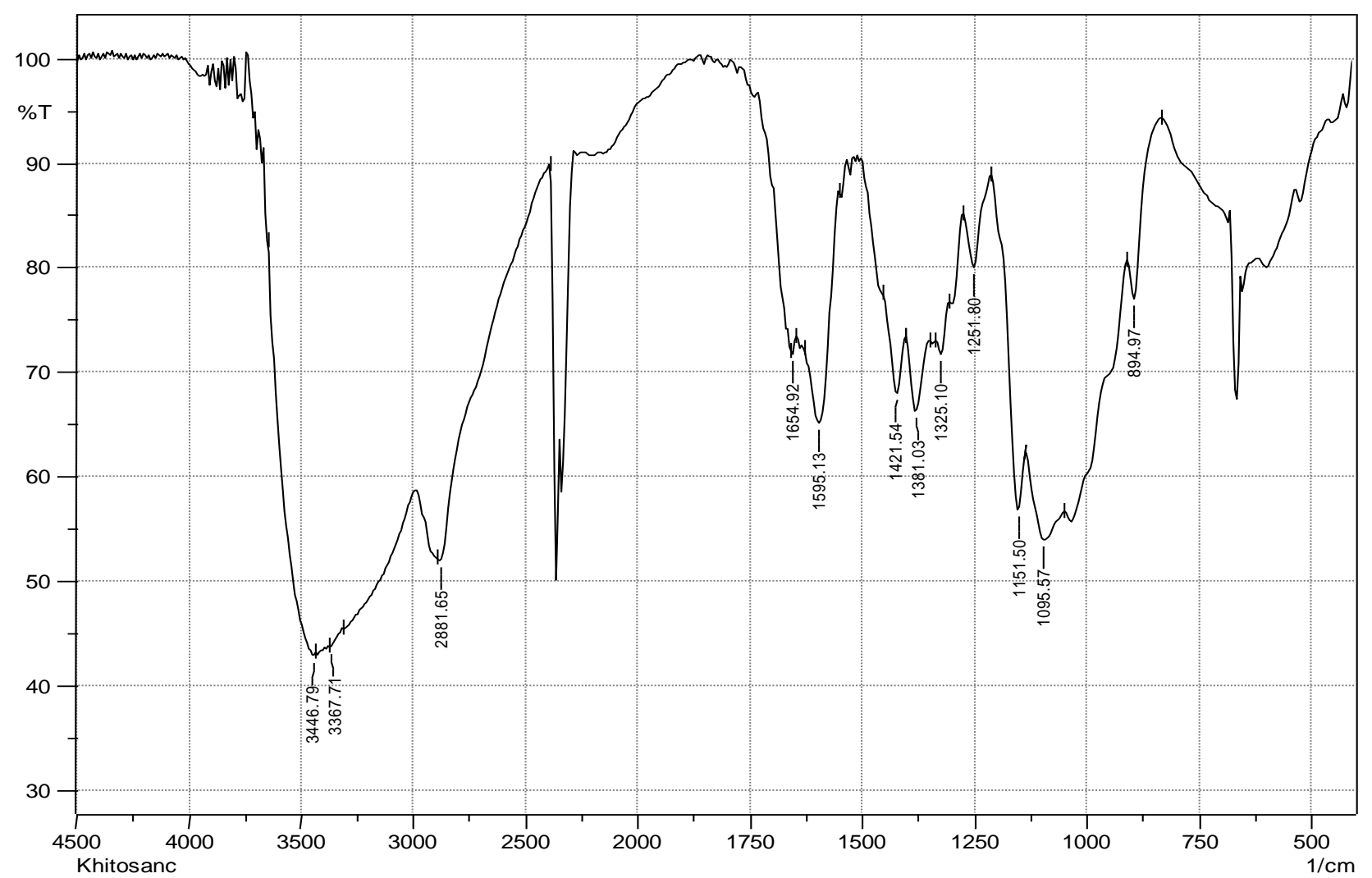

Gambar 3. Spektrum FTIR Kitosan

Ikatan yang terdapat di dalam kitosan terangkum dalam Tabel 2 di bawah ini.

Tabel 2. Jenis-jenis ikatan pada struktur kitosan.

\begin{tabular}{ccc}
\hline $\begin{array}{c}\text { Bilangan } \\
\text { gelombang }\end{array}$ & $\begin{array}{c}\text { Jenis } \\
\text { Ikatan }\end{array}$ & Keterangan \\
\hline $1200-1705 \mathrm{~cm}^{-1}$ & $\mathrm{C}-\mathrm{O}-\mathrm{C}$ & Eter siklik \\
$1680-1630 \mathrm{~cm}^{-1}$ & $\mathrm{C}=\mathrm{O}$ & Asetamida \\
$3200-3600 \mathrm{~cm}^{-1}$ & $\mathrm{O}-\mathrm{H}$ & hidroksi \\
$3500-3300 \mathrm{~cm}^{-1}$ & $\mathrm{~N}-\mathrm{H}$ & Vibrasi stretching \\
1380 & $\mathrm{C}-\mathrm{H}$ & $\mathrm{CH}_{3}$ pada Amida \\
$1050+-10 \mathrm{~cm}^{-1}$ & $\mathrm{C}-\mathrm{O}$ & Alkohol primer \\
$1100 \mathrm{~cm}^{-1}$ & $\mathrm{C}-\mathrm{O}$ & Alkohol sekunder \\
\hline
\end{tabular}

Analisis lain yang dilakukan pada penelitian ini adalah pengukuran derajat deasetilasi dengan metoda baseline pada sepektrum inframerah.
Metode ini di adopsi dari penelitian Brugnerotto, dkk. [11] dengan menggunakan rumus:

$\% \mathrm{~N}$-deasetilasi $=\left\{100-\left[\left(\frac{\mathrm{A}_{1658}}{\mathrm{~A}_{3448}}\right) \times \frac{1}{1,33}\right]\right\} \times 100 \%$

dimana $\mathrm{A}_{1658}$ merupakan nilai absorban pada bilangan gelombang $1658 \mathrm{~cm}^{-1}$ yang merupakan pita amida yang menunjukkan jumlah gugus $\mathrm{N}$ asetil, sedangkan $\mathrm{A}_{3448}$ merupakan nilai absorban pada bilangan gelombang $3448 \mathrm{~cm}^{-1}$ yang merupakan pita $\mathrm{O}-\mathrm{H}$ hidroksil sebagai standar dalam. Faktor ' 1,33 ' dinyatakan sebagai nilai perbandingan $\mathrm{A}_{1658} / \mathrm{A}_{3448}$ untuk semua gugus $\mathrm{N}$ asetil pada kitosan terdeasetilasi. Pada penelitian ini diperoleh nilai derajat deasetilasi mencapai $79,31 \%$, sedangkan berdasarkan literatur, disebutkan bahwa dikatakan kitosan ketika 
besarnya nilai derajat deasetilasi lebih dari $70 \%$. Pengukuran derajat deasetilasi memberikan karakteristik tertentu pada kitosan, yaitu nilai berat molekul rata-rata. Berat molekul rata-rata yang diperoleh dari hasil deasetilasi sebanyak $1,16 \times 10^{7}$ $\mathrm{g} / \mathrm{mol}$. Pengukuran berat molekul ini sangat besar bila dibandingkan dengan literatur berkisar 1,0 $\mathrm{x} 10^{4}-1,0 \mathrm{x} 10^{6} \mathrm{~g} / \mathrm{mol}$. Hal ini dikarenakan perbedaan derajat deasetilasi. Semakin besar nilai derajat deasetilasinya, maka nilai berat molekul rata-rata dari kitosan akan berkurang.

\section{Membran Kitosan dan Membran Kitosan-TEOS}

Pembuatan Membran kitosan dapat dilakukan dengan inversi fasa, yaitu proses transformasi polimer dari fasa cair ke fasa padat dengan kondisi terkendali penguapan pelarut pada suhu tertentu [12] tahapannya adalah dengan membuat larutan kitosan 1\% sebagai larutan cetak, yang kemudian di cetak ke dalam suatu cawan petri dengan volume $20 \mathrm{~mL}$,selanjutnya pelarut dibiarkan menguap sehingga yang tertinggal adalah endapan polimer yang tercetak di dalam cawan petri. Untuk melepaskan membran tersebut dapat dilakukan dengan perendaman dengan larutan $\mathrm{NaOH} 2 \mathrm{M}$, kemudian didiamkan selama kurang lebih 30 menit, dan membran siap diangkat, yang kemudian dicuci dengan aqua $\mathrm{dm}$ untuk menghilangkan larutan $\mathrm{NaOH}$ yang menempel. Pada proses ini, larutan $\mathrm{NaOH}$ berperan sebagai nonpelarut atau suatu koagulan. Dengan metoda inversi fasa ini dapat diperoleh membran yang porous.

Proses selanjutnya adalah sintesis membran kitosan-TEOS, yaitu mengikatsilangkan suatu material anorganik yaitu tetraetilortosilikat (TEOS) kedalam suatu polimer organik. Tahap sintesis dilakukan dengan penambahan langsung TEOS kedalam larutan kitosan $1 \%$ melaui proses sol-gel. Proses ini melibatkan dua reaksi yaitu reaksi hidrolisis dan reaksi kondensasi, mekanisme yang terjadi dapat dilihat pada Gambar 4.

Reaksi hidrolisis:
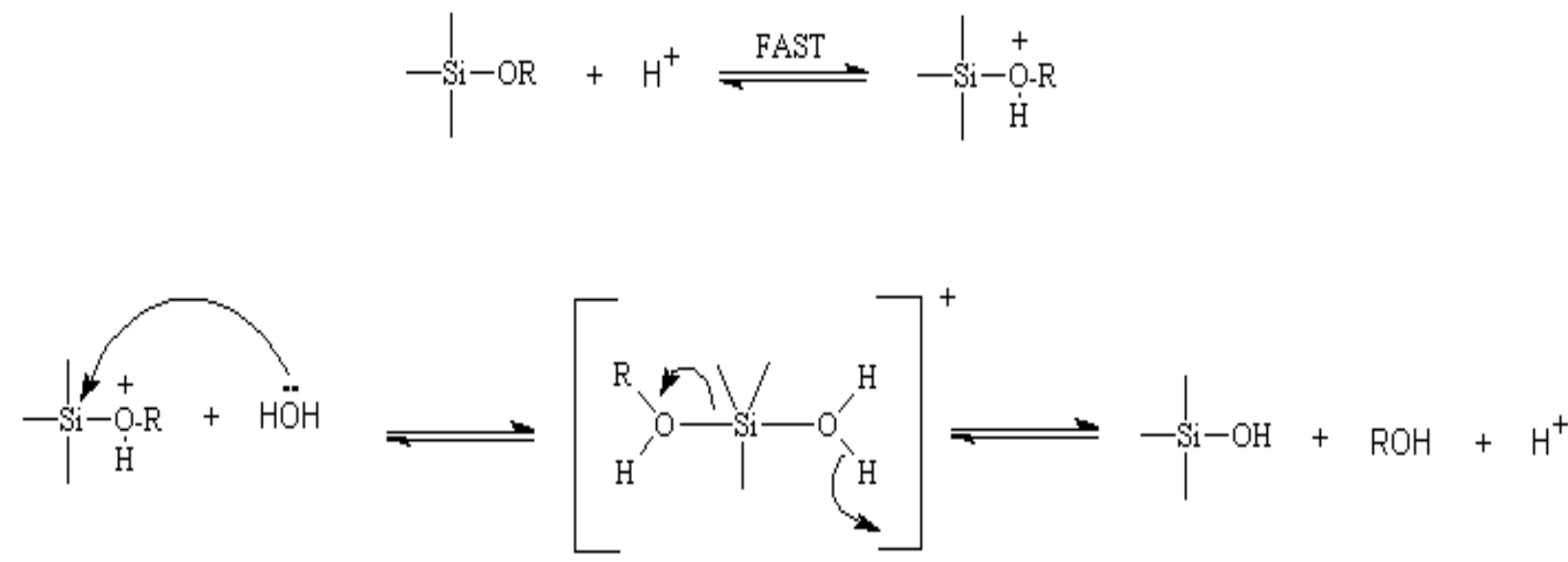

Reaksi kondensasi:

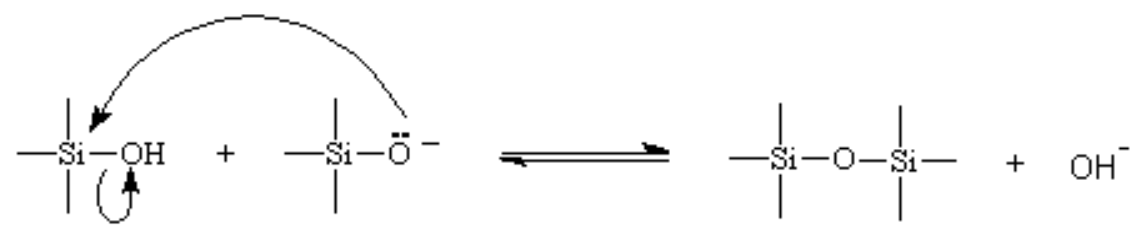

Gambar 4. Usulan Mekanisme Reaksi Sintesis Membran Kitosan-TEOS dengan Metode Sol-Gel [13].

Membran kitosan serta turunannya yang berhasil disintesis yaitu CTSN; CTSN-0,5; CTSN1; CTSN-1,5; serta CTSN-2. Angka dibelakang kode CTSN menyatakan volume $(\mathrm{mL})$ TEOS yang ditambahkan. Untuk membuktikan CTSN bereaksi dengan TEOS dan terjadi pengikatsilangan, dilakukan pengukuran berat molekul rata-rata, dan juga dilakukan pengukuran spektrum inframerah terhadap membran. Pada pengukuran berat molekul terdapat perbedaan dimana $\mathrm{BM}$ CTSN $=1,16 \times 10^{7}$
Da, sedangkan pada membran CTSN-1,5 BM= $2,23 \times 10^{7} \mathrm{Da}$. Dari data ini dapat diperoleh berapa banyak TEOS yang terikat silang. Selisih BM jika dibagi dengan $\mathrm{Mr}$ dari TEOS, diperoleh 51.612 molekul TEOS yang terikat. Pada pengukuran spektrum inframerah dengan penggunaan pelet $\mathrm{KBr}$, hasil spektrum yang diperoleh terlihat pada Gambar 5. Tipe membran yang digunakan adalah CTSN-1,5. 


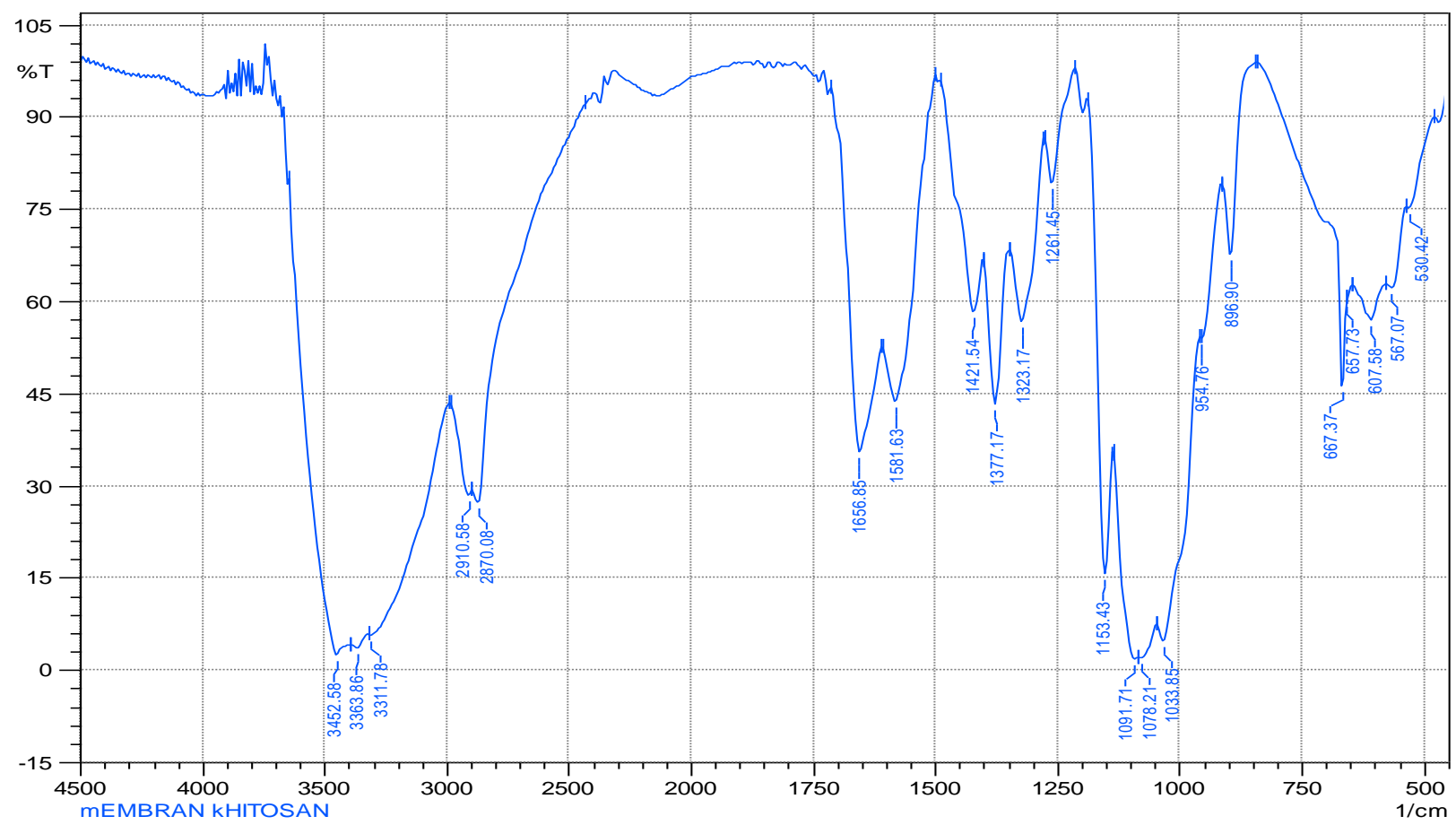

Gambar 5. Spektrum inframerah 41emperat kitosanTEOS.

Ikatan yang terbentuk antara senyawa kitosan dan TEOS terangkum dalam Tabel 3 di bawah ini.

Tabel 3. Jenis-Jenis Ikatan Pada Membran KitosanTEOS

\begin{tabular}{cc}
\hline $\begin{array}{c}\text { Bilangan } \\
\text { gelombang }\left(\mathbf{c m}^{-1}\right)\end{array}$ & Ikatan \\
\hline $910-830 \mathrm{~cm}^{-1}$ & $\mathrm{Si}-\mathrm{OH}$ \\
$1110-1000 \mathrm{~cm}^{-1}$ & Si-O-Si dan Si-O-C (alifatik) \\
$2250-2100 \mathrm{~cm}^{-1-}$ & $\mathrm{Si}-\mathrm{H}$ ulur \\
$1200-1705 \mathrm{~cm}^{-1}$ & $\mathrm{C}-\mathrm{O}-\mathrm{C}$ eter siklik \\
$1680-1630 \mathrm{~cm}^{-1}$ & $\mathrm{C}=\mathrm{O}$ amida
\end{tabular}

$$
\begin{gathered}
3200-3600 \mathrm{~cm}^{-1} \\
3500-3300 \mathrm{~cm}^{-1} \\
1380 \\
1050+-10 \mathrm{~cm}^{-1} \\
1100 \mathrm{~cm}^{-1}
\end{gathered}
$$

Kemungkinan besar pengikatsilangan yang terbentuk adalah antara gugus $-\mathrm{CH}_{2} \mathrm{O}-\mathrm{Si}-\mathrm{O}-\mathrm{Si}$ (ikatan Si-O-R ,R=alifatik), hal ini ditunjukkan dengan adanya puncak pada bilangan gelombang 1110-1000 $\mathrm{cm}^{-1}$ sedangkan gugus $\mathrm{NH}_{2}$ tetap menjadi gugus amina bebas. Usulan mekanisme pengikatsilangan dapat terlihat Gambar 6.

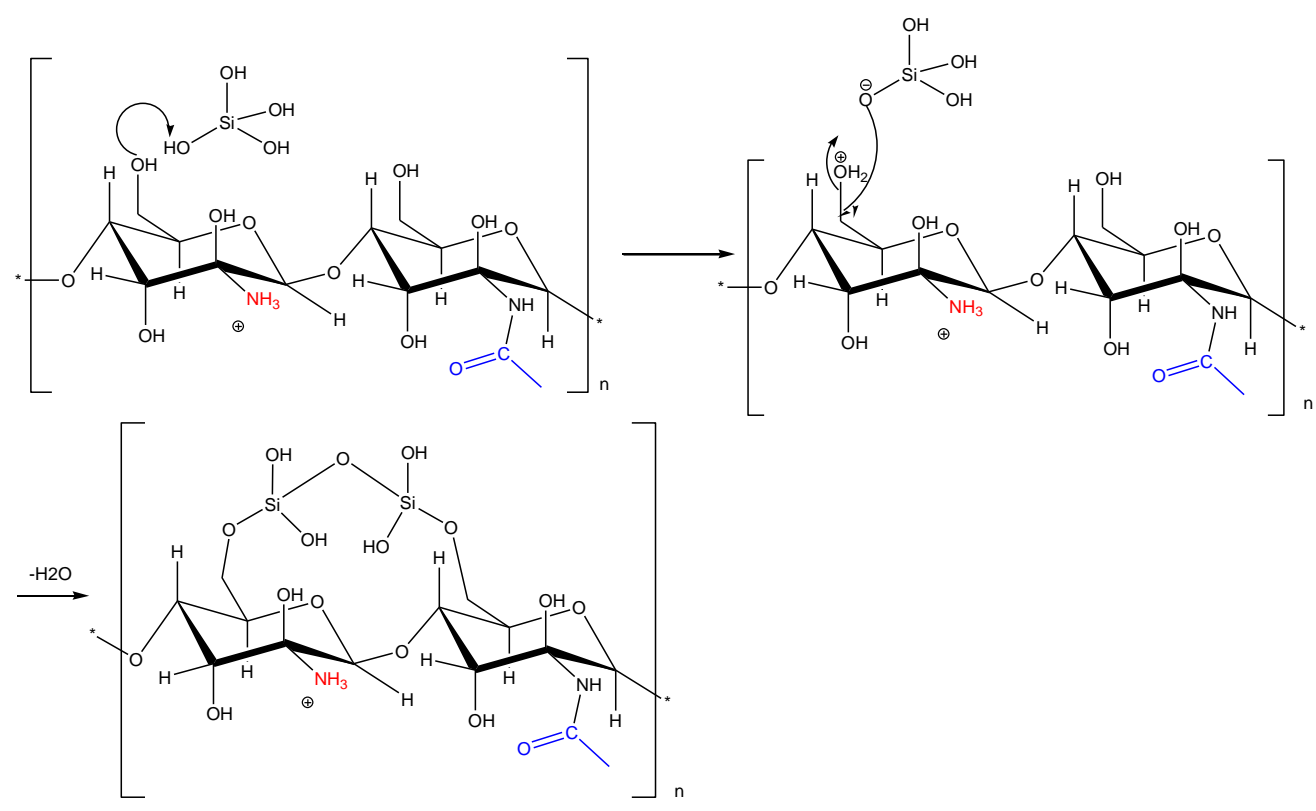

Gambar 6. Mekanisme Reaksi Pengikatsilangan Kitosan-TEOS. 
Analisis kehilangan berat pada berbagai suhu. Pengukuran persen masa yang hilang terhadap pengaruh 42emperature terangkup di dalam Tabel $\mathbf{4}$ di bawah ini.

Tabel 4. Data persen kehilangan berat pada berbagai suhu

\begin{tabular}{ccccc}
\hline $\begin{array}{c}\text { Tipe } \\
\text { Membran }\end{array}$ & $\begin{array}{c}\text { Suhu } \\
\mathbf{6 0}^{\mathbf{C}} \mathbf{C}\end{array}$ & $\begin{array}{c}\text { Suhu } \\
\mathbf{8 0}^{\mathbf{C}} \mathbf{C}\end{array}$ & $\begin{array}{c}\text { Suhu } \\
\mathbf{1 0 0}^{\mathbf{C}} \mathbf{C}\end{array}$ & $\begin{array}{c}\text { Suhu } \\
\mathbf{1 2 0}^{\boldsymbol{0}} \mathbf{C}\end{array}$ \\
\hline CTSN & $3,03 \%$ & $2,22 \%$ & $14,53 \%$ & $11,53 \%$ \\
CTSN-0,5 & $3,43 \%$ & $8,23 \%$ & $12,70 \%$ & $16,67 \%$ \\
CTSN-1 & $3,33 \%$ & $1,01 \%$ & $16,27 \%$ & $20,40 \%$ \\
CTSN-1,5 & $1,73 \%$ & $5,08 \%$ & $11,37 \%$ & $43,75 \%$ \\
CTSN-2 & $8,90 \%$ & $32,45 \%$ & $14,22 \%$ & $14,76 \%$ \\
\hline
\end{tabular}

Hasil penelitian menunjukkan telah terjadi kenaikan persen kehilangan massa dari membran dengan meningkatnya temperatur. Dengan kata lain, semakin besar suhu yang digunakan maka semakin besar juga massa membran yang hilang. Hal ini disebabkan oleh lepasnya $\mathrm{H}_{2} \mathrm{O}$ melalui reaksi intramolekul selama pemanasan berlangsung. Begitupun pada fisik membran terjadi perubahan warna membran dari transparan menjadi kekuningan. Ini menunjukkan bahwa membran telah mengalami degradasi.

Salah satu karakteristik membran yang dapat digunakan sebagai elektrolit di dalam fuel cell adalah derajat penyerapan airnya. Nilai ini ditentukan dengan metode gravimetri yaitu dengan menghitung selisih massa basah dengan massa kering dari membran. Nilai ini juga menentukan sifat fisik dari membran, apakah tahan terhadap air atau tidak, karena di dalam aplikasinya menggunakan larutan metanol (ada kandungan airnya). Makin banyak air yang diserap, biasanya konduktivitas membran akan meningkat. Hal ini disebabkan oleh peranan molekul air yang dapat membuat spesi pembawa muatan terdisosiasi dan mempermudah mobilitas spesi tersebut, yaitu proton. Tetapi ada batasannya, jika derajat penyerapannya terlalu tinggi (lebih dari 50\%) maka membran menjadi lunak. Sehingga life time membran akan singkat. Meningkatnya gugus yang hidrofil akan meningkatkan derajat penyerapan air. Tabel 5 menunjukkan derajat penyerapan air pada membran kitosan-TEOS pada berbagai suhu.

Tabel 5. Data persen penyerapan air pada variasi suhu.

\begin{tabular}{lcccc}
\hline $\begin{array}{c}\text { Tipe } \\
\text { Membran }\end{array}$ & $\begin{array}{c}\text { suhu } \\
\mathbf{2 5}^{\mathbf{0}} \mathbf{C}\end{array}$ & $\begin{array}{c}\text { Suhu } \\
\mathbf{8 0}^{\mathbf{0}} \mathbf{C}\end{array}$ & $\begin{array}{c}\text { suhu } \\
\mathbf{1 0 0}^{\mathbf{0}} \mathbf{C}\end{array}$ & $\begin{array}{c}\text { suhu } \\
\mathbf{1 2 0}^{\mathbf{0}} \mathbf{C}\end{array}$ \\
\hline CTSN & $4,34 \%$ & $20,51 \%$ & $69,32 \%$ & $2,17 \%$ \\
CTSN-0,5 & $5,71 \%$ & $10,19 \%$ & $7,50 \%$ & $4,50 \%$ \\
CTSN-1 & $4,54 \%$ & $39,35 \%$ & $59,31 \%$ & $2,77 \%$ \\
CTSN-1,5 & $3,70 \%$ & $64,42 \%$ & $21,93 \%$ & $4,13 \%$ \\
CTSN-2 & - & $52,03 \%$ & $68,24 \%$ & $3,71 \%$ \\
\hline
\end{tabular}

Kitosan memiliki rantai utama yang hidrofilik karena adanya gugus amina bebas dan gugus hidroksi pada atom C-6. Dengan adanya penambahan volume TEOS, berarti akan meningkatkan derajat hidrofilisitas dari rantai utama kitosan. Hal ini berimbas pada meningkatnya derajat penyerapan airnya.

Pada Tabel 5 juga menunjukkan dengan meningkatnya suhu pemanasan, nilai persen penyerapan air kecenderungannya semakin besar. Hal ini dikarenakan semakin banyak spesi yang menambah sifat hidrofilisitasnya, yaitu gugus hidroksi, namun ketika suhu pemanasan mencapai $120^{\circ} \mathrm{C}$, nilai persen penyerapan airnya menurun drastis. Hal ini disebabkan oleh dampak dari degradasi membran yang cukup tinggi dengan melihat penurunan nilai persen berat membran pada suhu $120^{\circ} \mathrm{C}$. Sehingga ada kemungkinan lepasnya molekul air pada interaksi intramolekul semakin banyak.

\section{Analisis Kapasitas Penukar Ion}

Kapasitas penukar ion menunjukkan jumlah gugus ionik dalam matriks polimer yang secara tidak langsung berkaitan dengan konduktivitas proton suatu polimer.

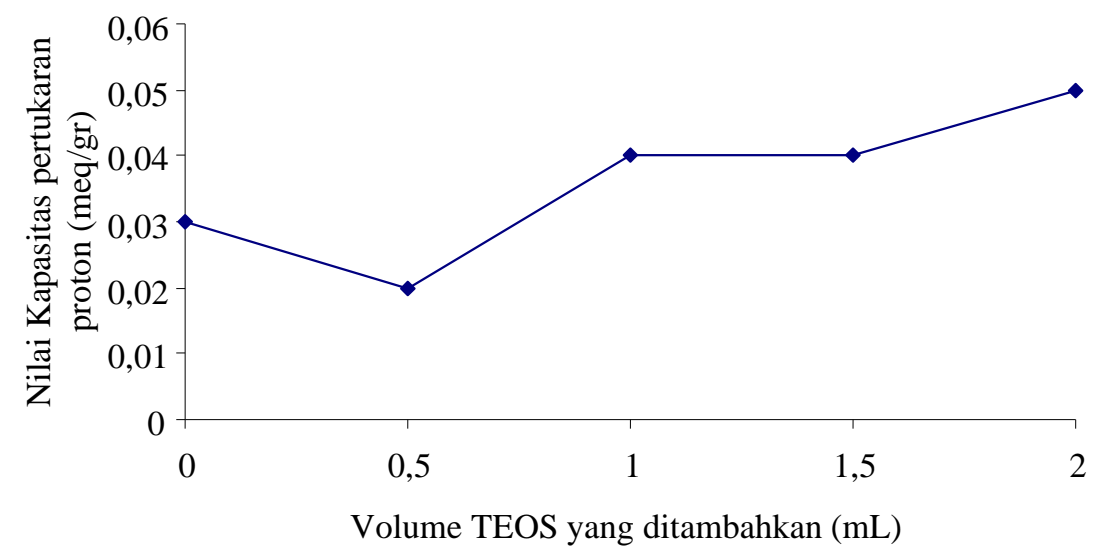

Gambar 7. Grafik Perubahan nilai ion $\mathrm{H}^{+}$variasi penambahan TEOS. 
Gambar 7 menunjukkan hasil nilai kapasitas penukar ion pada suhu $60^{\circ} \mathrm{C}$, dengan meningkatnya penambahan volume TEOS, maka nilai kapasitas penukar ion cenderung meningkat. Begitupun dengan kenaikan suhu hingga $100^{\circ} \mathrm{C}$ terjadi peningkatan nilai kapasitas pertukaran ionnya. Hal ini membuktikan bahwa di dalam struktur kitosan hanya memiliki gugus $\mathrm{NH}_{2}$ sebagai gugus ioniknya, sedangkan pada membran CTSN-TEOS terdapat gugus $\mathrm{NH}_{2}$ dan gugus $\mathrm{Si}-\mathrm{OH}$ yang dapat bertindak sebagai gugus ioniknya. Sedangkan pada suhu $120^{\circ} \mathrm{C}$, terjadi penurunan nilai pertukaran ion, hal ini menunjukkan adanya hubungan dengan proses degradasi, dimana ketika terjadi proses degradasi dengan peningkatan suhu, gugus-gusus ionik seperti $-\mathrm{OH}^{-}$yang berkompeten untuk dapat menukarkan proton, mengalami interaksi dengan gugus silanol $(\mathrm{Si}-\mathrm{OH})$ membentuk ikatan $\mathrm{Si}-\mathrm{O}-\mathrm{Si}$.

Berdasarkan data yang diperoleh, dan terlihat pada Tabel 6 menunjukkan bahwa nilai kapasitas penukar ion tertinggi dimiliki oleh type membran CTSN-1,5 yaitu $0,114 \mathrm{meq} / \mathrm{g}$. Yang ternyata masih berada jauh dibawah nilai kapasitas penukar ion pada Nafion yang mencapai $0,9 \mathrm{meq} / \mathrm{g}$.
Tabel 6. Data Nilai Ion $\mathrm{H}^{+}$(meq/g) parameter suhu.

\begin{tabular}{ccccc}
\hline $\begin{array}{c}\text { Tipe } \\
\text { Membran }\end{array}$ & $\begin{array}{c}\text { Suhu } \\
\mathbf{2 5}^{\mathbf{0}} \mathbf{C}\end{array}$ & $\begin{array}{c}\text { Suhu } \\
\mathbf{6 0}^{\mathbf{}} \mathbf{C}\end{array}$ & $\begin{array}{c}\text { Suhu } \\
\mathbf{1 0 0}^{\mathbf{C}} \mathbf{C}\end{array}$ & $\begin{array}{c}\text { Suhu } \\
\mathbf{1 2 0}^{\mathbf{C}} \mathbf{C}\end{array}$ \\
\hline CTSN-0,5 & 0,01 & 0,02 & 0,09 & 0,04 \\
CTSN-1 & 0,01 & 0,04 & 0,01 & 0,01 \\
CTSN-1,5 & 0,02 & 0,04 & 0,11 & 0,07 \\
CTSN-2 & - & 0,05 & 0,07 & 0,04 \\
\hline
\end{tabular}

\section{Analisis Permeabilitas Metanol.}

Besarnya nilai permeabilitas metanol menjadi faktor utama untuk melihat berapa besar nilai metanol cross-over yang terjadi pada sistem fuel cell. Hal ini akan berdampak kepada besarnya nilai konduktivas yang dihasilkan. Besarnya nilai permeabilitas metanol ditunjukkan dengan adanya proses difusi metanol melewati membran. Untuk melihat kemampuan membran dalam melewatkan proton dan transport metanol dinyatakan dengan nilai fluks (J), yang didasarkan pada hukum pertama Fick's. Berdasarkan analisis kromatograpi gas (GC) diperoleh kurva aluran konsentrasi metanol pada kompartemen permeat terhadap waktu.

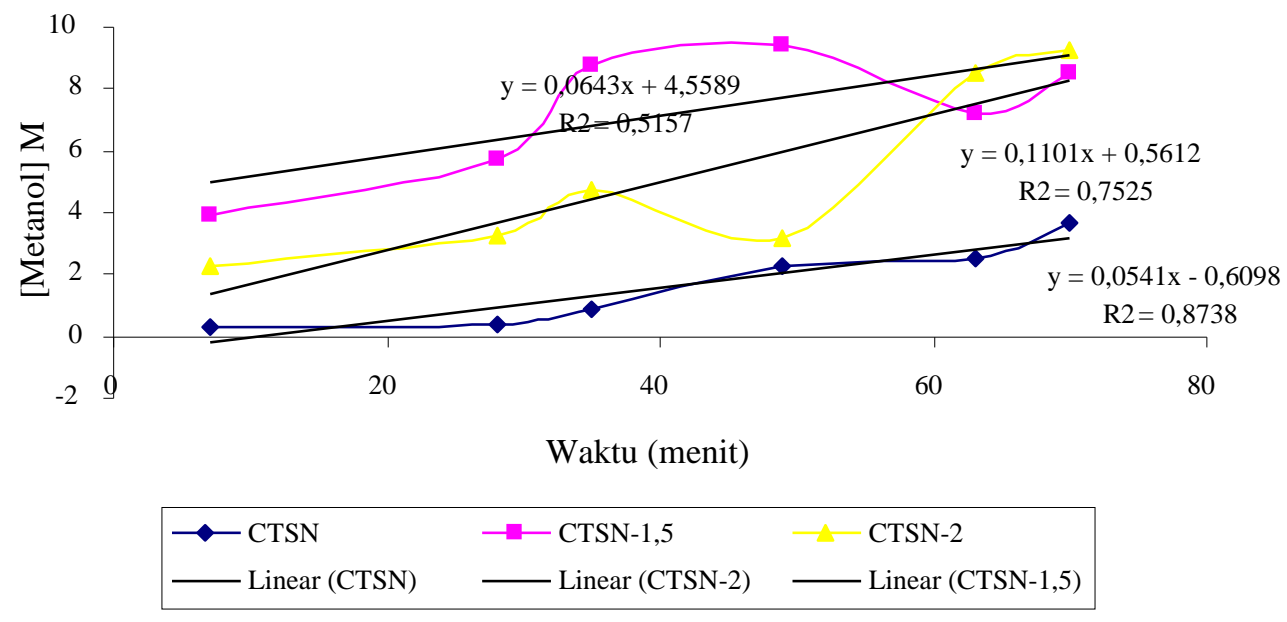

Gambar 8. Kurva Perubahan konsentrasi metanol terhadap waktu permeasi.

Gambar 8 menunjukkan bahwa dengan meningkatnya waktu permeasi, maka semakin banyak metanol yang berdifusi, walaupun ada kalanya metanol berdifusi kembali ke kompartemen umpan. Berdasarkan persamaan yang diungkapkan oleh Li dkk. [14]. Besarnya nilai permeabilitas metanol dapat diperoleh dengan menghitung terlebih dahulu besarnya nilai koefisien permeabilitasnya, yaitu dengan mengalurkan kurva antara - $\mathrm{ln}$ Cf/Co terhadap waktu. Dimana $C_{f}$ menyatakan besarnya nilai konsentrasi metanol yang melewati membran, sedangkan untuk $\mathrm{C}_{0}$ menyatakan besarnya nilai konsentrasi metanol awal dengan menggunakan rumus:

$$
-\ln \frac{C_{f}}{C_{0}}=\frac{A x p}{V_{f}} x t
$$

yang merupakan turunan dari hukum Fick's pertama .

Kemiringan dari kurva yang diperoleh dinyatakan sebagai koefisien permeabilitas $\left(\mathrm{p}, \mathrm{cm}^{3}\right.$ $\mathrm{cm}^{-2}$ ), kurva yang diperoleh seperti terlihat pada Gambar 9 di bawah ini. 


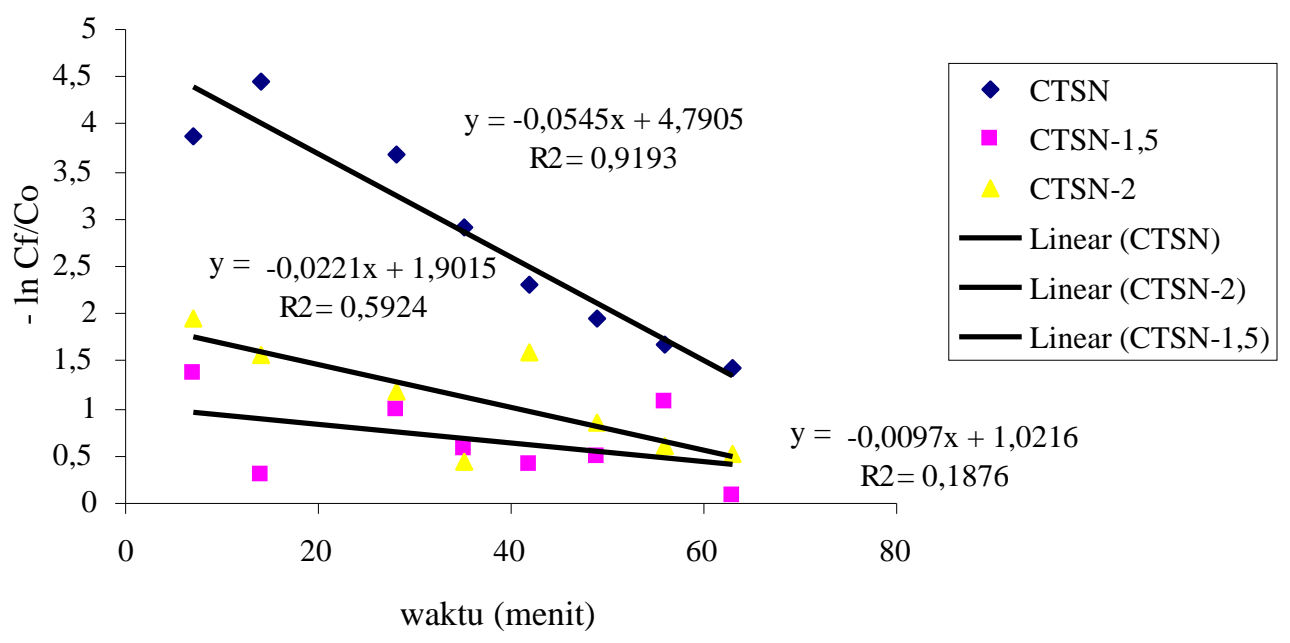

Gambar 9. Grafik penentuan koefisien permeabilitas metanol.

Besarnya nilai permeabilitas yang diperoleh kemudian digunakan untuk memperoleh nilai fluks dan selektivitas membran sebagai karakteristiknya.
Diperoleh nilai permeabilitas metanol seperti terlihat pada Tabel 7 di bawah ini.

Tabel 7. Data permeabilitas metanol pada membran.

\begin{tabular}{cccccc}
\hline No & $\begin{array}{c}\text { Tipe } \\
\text { Membran }\end{array}$ & $\begin{array}{c}\text { Permeabilitas } \\
\left(\mathrm{cm}^{2} / \text { menit }\right)\end{array}$ & $\begin{array}{c}\text { Fluks } \\
\text { proton }\end{array}$ & $\begin{array}{c}\text { Fluks } \\
\text { metanol }\end{array}$ & $\begin{array}{c}\text { Selektivitas } \\
\text { membran }\end{array}$ \\
\hline 1 & CTSN & 0,20 & 0,85 & 0,17 & 5,13 \\
2 & CTSN-1,5 & 0,22 & 0,15 & 0,03 & 4,71 \\
3 & CTSN-2 & 0,01 & 0,34 & 0,001 & 0,00044 \\
\hline
\end{tabular}

Adapun nilai selektivitas dinyatakan dengan persamaan:

$$
\alpha=\frac{J_{H^{+}}}{J_{\text {methanol }}}
$$

Berdasarkan Tabel 7, menyatakan bahwa CTSN tanpa TEOS memberikan hasil yang lebih baik.

\section{Analisis Konduktivitas Membran}

Besarnya nilai konduktivitas proton suatu membran merupakan parameter optimalisasi penggunaan membran tersebut sebagai elektrolit dalam sistem fuel cell. Pada penelitian ini dilakukan pada satu frekuensi $50 \mathrm{~Hz}$ karena keterbatasan alat serta waktu. Dengan mengetahui $\mathrm{R}_{\mathrm{m}}$ (tahanan membran) hasil konversi dari hantaran, maka konduktivitas dapat ditentukan dengan persamaan yaitu:

$$
\sigma=\frac{l}{R A}
$$

dimana nilai tahanan diperoleh dari 1/hantaran (S). Dari data yang diperoleh pada frekuensi $50 \mathrm{~Hz}$, dengan meningkatnya volume TEOS yang ditambahkan, nilai konduktivitasnya meningkat.
Hal ini ada kesesuaian dengan meningkatnya nilai persen kehilangan massa pada suhu $100^{\circ} \mathrm{C}$, karena terbentuknya ikatan silang yang memungkinkan terjadi penyempitan pori-pori pada membran. Nilai konduktivitas proton dari CTSN-1,5 terlihat pada Gambar 10.

Pengukuran dilakukan dalam keadaan basah, diharapkan dengan adanya spesi air didalam matriks polimer, sehingga spesi-spesi pembawa muatan akan terdisosiasi oleh air dan dapat bergerak menghantarkan proton. Makin banyak jumlah molekul air dalam matriks polimer maka konduktivitas akan meningkat. Hal ini disebabkan oleh spesi pembawa muatan yang terdisosiasi bertambah banyak dan pergerakannya pun akan semakin cepat. Adanya gugus ionik dalam matriks polimer seperti hidroksi akan meningkatkan konduktivitas, terutama pada keadaan basah. Mekanisme yang terjadi pada CTSN basah diperkirakan melibatkan spesi $\mathrm{OH}^{-}$sebagai spesi pembawa muatan. Gugus $\mathrm{NH}_{2}$ kitosan akan terprotonasi dalam air menjadi $\mathrm{NH}_{3}{ }^{+}$menurut reaksi:

$\mathrm{NH}_{2}+\mathrm{H}_{2} \mathrm{O} \rightarrow \mathrm{NH}_{3}{ }^{+}+\mathrm{OH}^{-}$

Spesi $\mathrm{OH}$ inilah yang bebas bergerak dan berkontribusi pada konduktivitas [15]. 


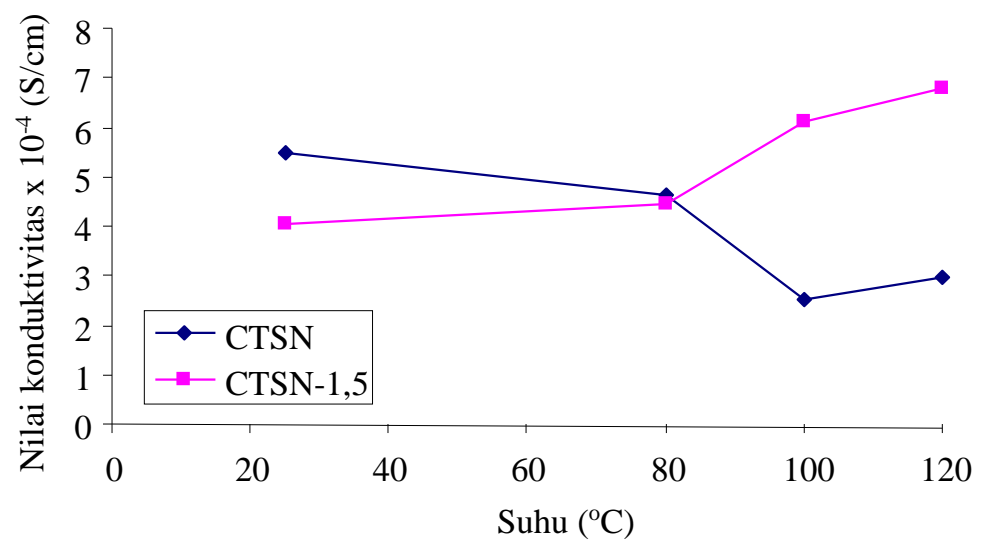

Gambar 10. Grafik Konduktivitas proton pada membran CTSN dan membran CTSN-1,5.

\section{Scanning Electron Microscopy (SEM)}

Teknik analisis yang dapat memberikan gambaran jelas mengenai struktur pori membran adalah Scanning Electron Microscopy (SEM) dapat dilihat pada Gambar 11.

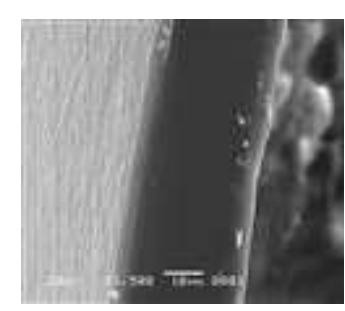

Penampang lintang CTSN

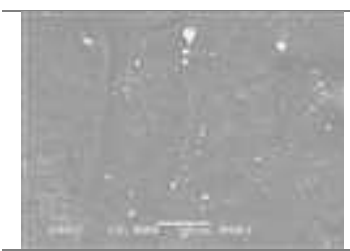

Kitosan permukaan bawah perbesaran $2000 \mathrm{x}$

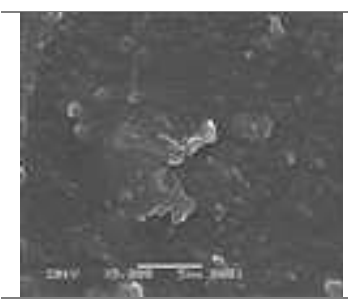

Kitosan permukaan atas perbesaran 5000

$\mathrm{x}$

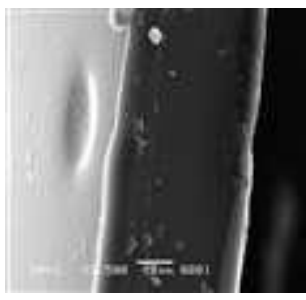

Penampang lintang CTSN-1,5

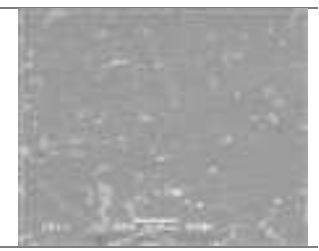

Kitosan-1,5 Permukaan bawah perbesaran $2000 \mathrm{x}$

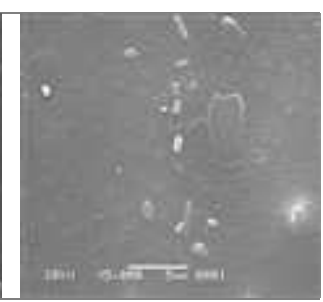

Kitosan-1,5 permukaan atas perbesaran $5000 \mathrm{x}$
Gambar 11. SEM dari Membran CTSN dan Membran CTSN-1,5.

Pada Gambar 11 memperlihatkan morphology dari membran. Ada korelasi ketika suatu membran yang memiliki nilai permeabilitas metanol besar, maka struktur porinya akan lebih besar. Serta terlihat pada penampang lintang yang menunjukkan adanya perubahan, pada kitosan poriporinya halus sedangkan pada membran kitosanTEOS 1,5 terdapat perubahan ukuran pori.

Semakin besar konsentrasi membran, permukaan dan penampang polimer akan semakin kompak dan rapat. Porositas permukaan membran pun menurun seiring dengan bertambahnya konsentrasi polimer. Peningkatan konsentrasi polimer akan mengurangi konsentrasi pelarut yang digunakan, sehingga pada saat koagulasi parsial pelarut, membran dengan konsentrasi polimer yang besar akan memiliki lapisan atas yang lebih kaya polimer, dan menghasilkan membran dengan lapisan aktif yang lebih rapat (dense).Terjadinya pengikatan silang antara TEOS dengan kitosan terlihat pada SEM dimana pori-porinya jauh lebih rapat, terlihat pada perbesaran 5000 kali.

\section{SIMPULAN}

Pemanfaatan kitosan dalam perkembangan teknologi serta ilmu pengetahuan sudah banyak dikembangkan, salah satunya sebagai membran elektrolit dalam sistem fuel cell. Pada penelitian ini, telah berhasil disintesis membran kitosan dengan derajat deasetilasi $79,31 \%$ beserta turunannya yaitu kitosan-TEOS yang berbasiskan silika dalam matriks polimer kitosan. Yang terbukti dengan munculnya gugus-gugus tertentu pada spektrum inframerah seperti adanya gugus $-\mathrm{NH}_{2}$ - primer bebas, $\quad-\mathrm{C}=\mathrm{O}$-amida dan ikatan silanol $(\mathrm{Si}-\mathrm{OH})$ maupun ikatan Si-O-R (alifatik). Keberadaan silika serta gugus silanol dalam matriks kitosan diharapkan dapat meningkatkan kinerja sistem DMFC (Direct Methanol Fuel Cell) . Hasil yang didapat, membran yang berhasil disintesis adalah CTSN; CTSN-0,5; CTSN-1; CTSN-1,5; serta CTSN-2. dengan karakteristik ketahanan membran terhadap suhu mencapai $120^{\circ} \mathrm{C}$. Nilai Pertukaran 
ion terbesar dimiliki oleh type membran CTSN-1,5 dengan nilai 0,114 meq/g. Pengukuran permeabilitas metanol menunjukkan perlunya modifikasi lain dalam turunan kitosan, karena nilainyat lebih besar dari kitosan. Sedangkan pada SEM terlihat perubahan ukuran pori.

\section{UCAPAN TERIMA KASIH}

Ucapan terimakasih disampaikan kepada Ibu Deana Wahyuningrum serta Bapak Muhammad Ali Zulfikar selaku pembimbing dan Program Studi Kimia ITB atas bantuan dan fasilitas untuk penelitian ini.

\section{REFERENSI}

[1] E. Agel, J. Bouet, and J.F. Fauvarque, "Characterization and use of anionic membranes for alkaline fuel cells", Journal of Power Sources, vol. 101, no. 2, pp. 267-274, 2001.

[2] D. Shekhawat, D.A. Berry, and J.J. Spivey, Introduction to fuel processing. In Fuel Cells: Technologies for Fuel Processing, Elsevier, pp. 1-9, 2011.

[3] L. JE and A. Dicks, Fuel cell system explained, 2nd edition, Chichester, UK: John Wiley and Sons, 2003.

[4] S.M. Haile, "Fuel Cell materials and components", Acta Materialia, vol. 51, no. 19, pp. 5981-6000, 2003.

[5] M. Rikukawa and K. Sanusi, "ProtonConducting polymer electrolyte membrane based on hydrocarbon polymers", Progress in Polymer Science, vol. 25, no. 10, pp. 1463 1502, 2000.

[6] B. Smitha, S. Sridhar, and A.A. Khan, "Chitosan-sodium alginate polyion complexes as fuel cell membranes", European Polymer Journal, vol. 41, no. 8, pp. 1859-1866, 2005.

[7] K.D. Kreuer, S.J. Paddison, E. Spohr, and M. Schuster, "Transport in proton conductors for fuel-cell applications: simulations, elementary reactions, and phenomenology", Chemical reviews, vol. 104, no. 10, pp. 4637 4678, 2004.
[8] K. Hong, K. Meyers, and K.S. Lee, "Isolation and characterization of chitin from crawfish shell waste", Journal of Agricultural and Food Chemistry, vol. 37, no. 3, pp. 575-579, 1989.

[9] M. Campo and J.G. Grigera, "Molecular dynamics simulation of $\mathrm{OH}-\mathrm{in}$ water", Molecular Simulation, vol. 30, no. 8, pp. 537542, 2004.

[10] A. Mokrini, and J.L. Acosta, "New ion conducting systems based on star branched block copolymer", Polymer, vol. 42, no. 21, pp. 8817-8824, 2011.

[11] J. Brugnerotto, J. Lizardi, F.M. Goycoolea, W. Argüelles-Monal, J. Desbrières, and M. Rinaudo, "An infrared investigation in relation with chitin and chitosan characterization", Polymer, vol. 42, no. 8, pp. 3569-3580, 2001.

[12] M. Mulder, Basic Principle of Membrane Technology, Netherlands: Kluwer Academic Publisher, pp. 210-278., 1996.

[13] L. Gabrielli, L. Russo, A.Poveda, J. R. Jones, F. Nicotra, JJ. Jiménez-Barbero, and L. Cipolla, "Epoxide opening versus silica condensation during sol-gel hybrid biomaterial synthesis", Chemistry A European Journal, vol. 19, no. 24, pp. 78567864., 2013.

[14] C. Li, G. Sun, S. Ren, J. Liu, Q. Wang, Z. Wu, and W. Jin, "Casting Nafion-sulfonated organosilica nano-composite membranes used in direct methanol fuel cells", Journal of membrane science, vol. 272, no. 1-2, pp. 5057, 2006.

[15] Y.Y. Wan, K.A.M. Creber, B.A. Peppley, and V.T. Bui, "Ionic conductivity and related properties of crosslinked chitosan membranes", Journal of Applied Polymer Science, vol. 89, no. 2, pp. 306-317, 2003. 